
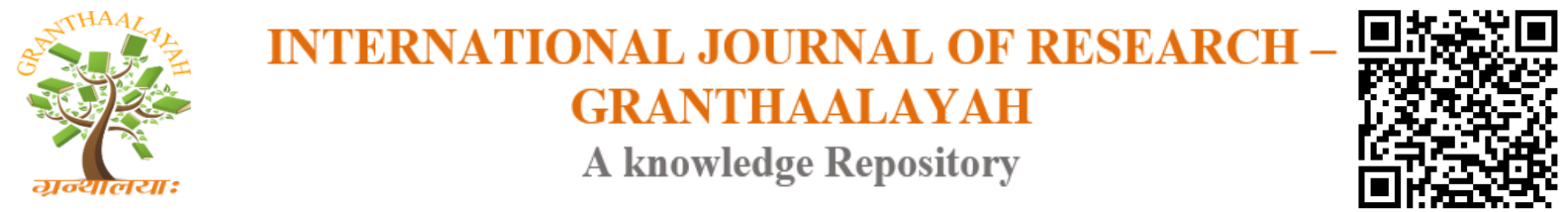

Management

\title{
INVESTIGATION OF THE RELATIONSHIP BETWEEN TRADE OPENNESS AND ECONOMIC GROWTH IN THE CASE OF CHINA
}

\author{
Masoud Ali Khalid ${ }^{1}$, Assist. Prof. Dr.Khalid Hayder A.Ali ${ }^{2,3}$ \\ ${ }^{1}$ College of Finance \& Administration, Department of Banking \& Financial Science, Cihan \\ University/ Sulaimani, Kurdistan Region Government/Iraq \\ ${ }^{2}$ Sulaimani University, College of Administration \& Economics, Department of Economic \\ ${ }^{3}$ College of Finance \& Administration, Department of Accounting by IT, Cihan University/ \\ Sulaimani, Kurdistan Region Government/Iraq
}

\begin{abstract}
In this paper, we have investigated the relationship between trade openness and long-run economic growth over the sample period 1960-2015, utilizing ARDL model. We found evidence that trade openness is directly correlated with economic growth in the long run. Furthermore, Granger Causality tests recommended that a change in trade openness impacts the long-run of economic growth through the interaction with gross capital formation in the case of China.
\end{abstract}

Keywords: Economic Growth; Trade; ARDL Model; China.

Cite This Article: Masoud Ali Khalid, and Assist. Prof. Dr.Khalid Hayder A.Ali. (2017). "INVESTIGATION OF THE RELATIONSHIP BETWEEN TRADE OPENNESS AND ECONOMIC GROWTH IN THE CASE OF CHINA." International Journal of Research Granthaalayah, 5(7), 199-213. https://doi.org/10.29121/granthaalayah.v5.i7.2017.2122.

\section{Introduction}

The world merchandise exports grew by $6 \%$ on average while the world GDP grew by around $3 \%$ in the second half of the 20th century (UNCTAD -2008). This development is even more discernible with the further integration of bigger economies such as China and India into the global economy. Does this imply that the world is to enjoy even higher long-term economic growth of material well-being as countries trade more and more with each other? This is one of the oldest questions in economic theory and has been extensively demonstrated and studied by new empirical researchers.

The results of previous empirical literature on the relationship between trade and economic growth are very sensitive to model specification. Even though some previous studies have addressed the problem of method uncertainty, their model is neither systematic nor complete. For example, applying "kitchen sink" exercises, Easterly and Levine (2003), Dollar and Kraay (2003), Alcalá and Ciccone (2004) and Rodrik et al. (2004), Masoud et al. (2016), carry out a 
"horse race" among institutional, geographical, and trade-related determinants of economic growth.

The main reason of this paper is to revisit the growth-trade openness relationship in the case of China in a time series over the sample period of 1960-2015

Furthermore, Rodrik and Rodríguez (2000), pointed out that, by measuring trade openness is a challenging task and most of the previous empirical study based on cross-section country growth comparison fail to provide a satisfactory openness measure. Since trade openness is defined as removing policy barriers to international trade rather than trade intensity, we attempt to employ ARDL model to measure directly the relationship between trade openness and economic growth.

In addition, another important concern in the openness-growth correlation is establishing the direction of causality: Does trade openness result in or from economic growth? In fact, this concern is valid for most of the economic growth theories considered in the study. Overcoming this problem is, nevertheless, a non-trivial issue not only because of extra computational burden required but also, even more importantly, difficulties in finding or constructing valid instrumental variables, particularly so when the number of regressors is enormous (Durlauf et al. (2008a), Mirestean and Tsangarides (2009) and Moral- Benito (2012).

For that reason, our findings reveal a good relationship between trade and economic growth and suggested explanatory variables, without establishing a direction of causality.

We have found that trade openness is associated with long term economic growth in the case of China, and it means that openness plays an important role to improve the Chine's economic growth.

The paper is organized as follows. The next section, Section 2, briefly reviews of Chinese economy. Section 3 discusses the literature on the relationship between trade openness and economic growth. Section 4 describes the methodology. Findings are presented and discussed in Section 5. Finally, Section 6 concludes.

\section{An overview of Chinese Economy}

China's international trade has experienced very rapid expansion together with its dramatic economic growth which has made the country target the world as its market. The stable political system, huge natural resources and plentiful skilled labor in China have made it a modern and global factory. International trade plays a major role in economic growth and productivity in China since several decades ago. Based on the previous literature internationally trade and active countries tend to be more productive than countries which only produce for their domestic market. Due to globalization and liberalization, a country's economy has become much more closely connected with external factors such as openness.

Thus, conducting and investigating on the impacts of international trade on economic growth is of great significance in this globalized era. It shows policymakers map out a proper policies by demonstrating the source of productivity growth with respect to international trade. Since the initiation of economic reforms and the adoption of the open door policy in China, international 
trade and China's economy have experienced dramatic growth rate. China's integration into the global market and economy has largely contributed to its sustained economic growth. Some of the big industries with comparative advantages have began to acquire a high level of specialization, and China has achieved a high growth rate of their GDP, as well as an vast inflow of hard currency and have increased in employment.

Furthermore, China's participation in international trade has also encouraged to rapid improvement in productivity of domestic industries and advancement of modern technology. On one hand, large imports of machinery goods in the early 1990s had an immediate effect on productivity through the application of technology embodied in them. On the other hand, the level of science and technology in China has increased dramatically due to the impact of "learning by doing." Therefore, study on how international trade contributed to China's economic growth can serve as a distinguishing case investigation demonstrating how a latecomer catches up with forerunners by increasing its participation on the global market.

\section{Literature Review}

In the previous literature, the correlation between trade openness and economic growth was based on the framework of the traditional Ricardian-Heckscher-Ohlin econometrics model. This model demonstrated that openness to international trade brings only a one-time increase in output, since the country allocates its resources more efficiently after opening up based on its comparative advantages, having no implications for long-run growth. Based on the neoclassical growth model it implies that per capita economic growth rate in the long-run is determined by exogenous technological progress. It also recommends that an increase in the saving rate creates a temporary increase in the growth rate. Additionally, openness may impact the long term growth rate if there is a technology-stimulating impact of openness.

On the other hand, neither the traditional Ricardian-Heckscher-Ohlin nor the neoclassical growth model provides a theoretical framework for the hypothesis that openness stimulates technological advancement.

In this regard, only more recent endogenous growth theories pay attention to the implications of trade openness on long-run growth.

The models of Rivera-Batiz and Romer (1991) and Grossman and Helpman (1991, Chapters 6 and 9), Maoud et al. (2017) offer a firmer theoretical framework relating trade policy to longterm economic growth rate. Based on these models, openness to international trade provides four distinct opportunities that may lead to long -term economic growth:

1) Communication impact: Openness to international trade offers opportunities for communicating with foreign counterparts, which in turn facilitate the transmission of technologies.

2) Duplication impact: In the absence of international trade, some ideas and technologies are duplicated in multiple countries.

3) Openness encourages firms to invent new ideas and technologies and, as a result, prevent duplication of research and development $(\mathrm{R} \& \mathrm{D})$ efforts. 
4) Integration impact: Trade openness raises the size of the market accessible to firms. Assuming that intermediate goods as well as final goods are traded across countries, larger market size of the R\&D sector increases R\&D activity and, thus, economic growth as this sector is subject to increasing returns to scale.

However, after opening up to trade, the domestic R\&D sector faces foreign competition and, as a result, may lose market share at home, leading to a slowdown in economic growth.

5) Allocation impact: Trade openness leads countries to specialize according to comparative advantages that are determined by factor endowments. Relative domestic prices of factors will alter after opening up to trade, as predicted by the Stolper-Samuelson theorem. If a country has a comparative advantage in a sector that is unskilled labor intensive, trade openness reduces the relative wage of skilled labor compared to unskilled labor. This leads to increase in the level of $\mathrm{R} \& \mathrm{D}$ activities, and, as a result, in the long-term growth rate, as the cost of $\mathrm{R} \& \mathrm{D}$ decreases and/or the fraction of skilled labor endowment employed in R\&D increases. The exact opposite takes place in a country that specializes in skilled-labor-intensive goods.

Among these different impacts, only the communication and duplication channels necessarily increase economic growth rate. On the other hand, the allocation and integration impacts are not unambiguously positive. Consequently, it is possible to conclude that the effect of openness to international trade on long-term economic growth depends on the magnitude and dominance of these different impacts. In addition, endogenous growth theory does not necessarily expect that openness leads to higher growth rate for all countries and under all circumstances.

The relationship between trade openness and economic growth has been the subject of a large number of theoretical and empirical studies. The main part of the previous empirical literature consists of the cross-country studies dating back to the 1970s. Early cross-country work (for example, Balassa (1978), Feder (1982), Ram (1987), inters alia) investigated the correlation between trade openness and economic growth in the framework of neoclassical growth accounting. They demonstrated that exports as a proxy for trade openness, and almost all of them conclude that export or outward trade orientation increases economic growth.

This issue drew renewed interest in the early 1990s, partly because of new analytical tools provided by endogenous growth model and a considerable number of liberalization reforms in less developed countries during the 1980s. Consistent with earlier cross-country studies, they affirm the positive and strong correlation between economic growth and trade openness. The salient feature of these studies is that they employ new openness measures directly addressing trade policy and orientation. Furthermore, these studies substantially benefit from the contributions of Barro (1991) and Mankiw et al. (1992) to cross-country growth empirics. New empirical researchers revisit the openness-growth correlation taking into account important growth determinants.

For instance, employing an openness measure based on international price deviations, Dollar (1992) concludes that openness is positively related with economic growth. Edwards (1992) 
found that strong evidence supporting more open countries and lead to grow faster in economics. In addition, Ben-David (1993) found absolute convergence in per capita income in a sample of open countries whereas closed countries do not tend to converge. Furthermore, Lee (1993), studied and demonstrated on the basis of "free trade openness", and measured as the import share in the absence of trade barriers, shows that the import-weighted tariff rate and the black market premium are detrimental to economic growth.

Ben-David (1996) also showed that countries tend to converge to the income level of their trading partners and, consequently, by undertaking trade, poor or developing countries can catch up with their richer trading partners. Introducing a new openness measure, the seminal paper by Sachs and Warner (1995) concludes a large positive impact of openness on growth. These authors also confirm Ben-David's (1993) result that open countries tend to converge whereas closed ones do not. Furthermore, Harrison (1996) found that various openness measures are significantly related with economic growth when a fixed effects growth model is estimated using panel data. Vamvakidis (1999) obtains a similar result between openness and investment in the same estimation framework by using the geographic component of trade as an instrument, Frankel and Romer (1999) showed that the international trade and per capita income, hence economic growth are strongly and positively linked and argue that the causality for this relationship runs from trade to the income level.

Both previous and recent studies, however, have been subject to some criticism. For instance, Edwards (1993) and Rodrik and Rodríguez (2000) heavily criticized the findings of the literature on lack of robustness grounds. Specifically, these studies emphasized two important drawbacks of the previous literature: First, the openness measures are poor proxies of trade policy stance and, in most cases, they are related with other aspects of macroeconomic policy and economic growth determinants. Second, most of the previous studies investigated the relationship between openness and economic growth by employing simple growth models, and avoiding some main important growth theories. Therefore, recent empirical studies have turned to examining the correlations between openness and growth, controlling for institutions and geography.

In other words, by running "kitchen sink" exercises, these studies carry out a "horse race" among geographical, institutional and trade-related determinants of economic growth (see, Easterly and Levine (2003), Alcalá and Ciccone (2004), Dollar and Kraay (2003), Rodrik et al. (2004). While these studies provided valuable information in order to understand the relative contributions of openness, institutions and geography to income level and, consequently, to economic growth, they are subject to model uncertainty issues since they tend to be based on a chosen set of economic growth determinants, as pointed out by Durlauf et al. (2008a).

In brief, it is worth highlighting the two important results emerging from the literature. Firstly, there is no theoretical justification for the proposition that trade openness unambiguously leads to higher long-term economic growth, making it an empirical question. Secondly, previous studies on the relationship between trade openness and economic growth are subject to fundamental methodological and econometric problems. In particular, they fail to provide a satisfactory measure of openness and generally ignore the model uncertainty issues. 


\section{Data Sources and Econometric Methodology}

\subsection{The Data}

The four variables are used in this study such as Gross domestic product per Capita Gross Capital Formation as a share of GDP, Export of Goods \& services as a share of GDP, Import of Goods \& services as a share of GDP by using time-series data for over the span 1960-2015 as illustrated in table I. The data are collected from World Development Indicator (WDI 2016).

\begin{tabular}{lll} 
Variable & Description & Table I: \\
\hline GDPC & Gross domestic product per Capita & WDI (2016) \\
GCF & Gross Capital Formation as a share of GDP & WDI (2016) \\
EXP & Export of Goods \& services as a share of GDP & WDI (2016) \\
IMP & Import of Goods \& services as a share of GDP & WDI (2016)
\end{tabular}

\subsection{Econometric Methodology}

To analyze time series data in different order I(1) and I(0) together, Pesaran et al. (2001) suggested, the Autoregressive distributed lag approach (ARDL) to test for co-integration as an alternative to co-integration model for Engle-Granger (1989). The study uses the ARDL model to investigate the long run and the short run relationship between variables. The ARDL bound testing approach for co-integration can be written as following:

$$
\begin{aligned}
\Delta \mathrm{GDPC}_{\mathrm{t}}= & \alpha_{0}+\sum_{\mathrm{i}=1}^{\mathrm{p}} \alpha_{1} \Delta \mathrm{GDPC}_{\mathrm{t}-\mathrm{i}}+\sum_{\mathrm{i}=0}^{\mathrm{p}} \alpha_{2} \Delta \mathrm{GCF}_{\mathrm{t}-\mathrm{i}}+\sum_{\mathrm{i}=0}^{\mathrm{p}} \alpha_{3} \Delta \operatorname{Exp}_{\mathrm{t}-\mathrm{i}}+\sum_{\substack{\mathrm{i}=0 \\
\mathrm{f}}}^{\mathrm{p}} \alpha_{4} \Delta \mathrm{IMP}_{\mathrm{t}-\mathrm{i}} \\
& +\mathrm{b}_{1} \mathrm{GDPC}_{\mathrm{t}-1}+\mathrm{b}_{2} \mathrm{GCP}_{\mathrm{t}-1}+\mathrm{b}_{3} \operatorname{Exp}_{\mathrm{t}-1}+\mathrm{b}_{4} \operatorname{Imp}_{\mathrm{t}-1}+\mu_{\mathrm{t}}
\end{aligned}
$$

Here $\Delta$ is the first difference operator; $\triangle \mathrm{GDPC}_{\mathrm{t}}$ refers for the natural log of Gross domestic product per capital, $\Delta \mathrm{GCF}_{\mathrm{t}}$ refers for the natural log of gross capital formation as a share of GDP, $\Delta$ Exp refers for the natural log of Export of Goods \& services as a share of GDP, $\Delta$ Imp refers for the natural $\log$ of Import of Goods \& services as a share of GDP, and $\mu_{\mathrm{t}}$ refers for the error correction term.

The $F$ test is used to determine whether the long-run relationship exists between the variables through testing the significance of the lagged levels of the variables. When the long-run relationship exists, the $F$ test will illustrate which variable should be normalized.

The null hypotheses of no co-integration amongst the variables are

$H_{0}: b_{1 i}=b_{2 i}=b_{3 i}=b_{4 i}=0$

Against the alternative hypothesis

$H_{1}: b_{1 i} \neq b_{2 i} \neq b_{3 i} \neq b_{4 i}=0$

for $\mathrm{i}=1,2,3,4$. 
The $F$ test has a standard distribution which depends on; (a) whether the variables are included in the ARDL model are I(0) or I(1); (b) the number of independent variables; (c) whether the ARDL model contains an intercept and a trend; and (d) the sample size of the variables. According to Narayan (2005), the rejection of the null depends on the F-test and the critical bound tabulated value for small sample size.

The long run relationship among the variables exists if the calculated value of $\mathrm{F}$ - statistic is greater than the upper critical bound (UCB), and if the calculated value of F- statistic is less than the lower critical bound (LCB), the long run relationship does not exist. If the calculated value of the F-statistic comes in between the range of LCB and UCB, then the long run relationship is inconclusive, Mintz (1990) Hassan \& Kalim, (2012). The optimal lag can be selected using the model selection criteria like Akaike Information Criterion (AIC). Narayan (2005) stated the maximum lags for small sample size is two lags.

\section{Results and Discussions}

We begin the empirical analysis with examine of the unit root test for the variables and we assumed that, the data used in this estimation are stationary. If the results of stationary are violated, this might lead to spurious results. In examining the time-series data properties, there are several models to test the stationary, but the most important one are the Augmented DickeyFuller (ADF) (Dickey and Fuller, 1979, 1981) and the Phillips-Peron (PP) (Phillips and Peron, 1988) unit root tests.

Table II explains the result of the stationary test for ADF and PP unit root test respectively for the case of China. Both tests have illustrated that GDPC has a unit root at level, but it becomes stationary at first difference, which implies that GDPC is I (1). In addition, all other variables are found to be significant at first difference and thus it indicates the variables are I (1) as we have illustrated at table III. As the results point out, the variables are either $\mathrm{I}(0)$ or $\mathrm{I}(1)$, therefore implying that we can confidently apply the ARDL approach to this model as using ARDL requires the data to be stationary at the level I(0) and first difference I(1) see (Narayan, 2005).

Table II: ADF and PP unit root tests on log levels of variables.

\begin{tabular}{|c|c|c|c|c|c|c|}
\hline \multirow[b]{2}{*}{ Variables } & \multicolumn{3}{|l|}{ ADF test } & \multicolumn{3}{|l|}{ PP test } \\
\hline & Intercept & $\begin{array}{l}\text { Intercept } \\
\text { trend }\end{array}$ & and & Intercept & $\begin{array}{l}\text { Intercept } \\
\text { trend }\end{array}$ & and \\
\hline $\ln (\mathrm{GDPC})$ & $4.127080^{\mathrm{a}}$ & $459037^{\mathrm{c}}$ & & $7.113549^{a}$ & $3.772046^{b}$ & \\
\hline $\ln (\mathrm{GCF})$ & -1.544535 & $-5.542900^{a}$ & & -1.648372 & $-5.741530^{a}$ & \\
\hline $\ln (\mathrm{EXP})$ & -0.835499 & -1.905174 & & -0.888832 & -2.200879 & \\
\hline $\ln (\mathrm{IMP})$ & -1.296312 & -2.631111 & & -1.013634 & -2.337133 & \\
\hline
\end{tabular}

${ }^{a}$ Denotes significant at $1 \%,{ }^{b}$ Denotes significant at $5 \%,{ }^{c}$ Denotes significant at $10 \%$, 
Table III: ADF and PP unit root tests on first differences of log levels of variables.

\begin{tabular}{|c|c|c|c|c|}
\hline \multirow[b]{2}{*}{ Variables } & \multicolumn{2}{|l|}{ ADF test } & PP test & \multirow[b]{2}{*}{$\begin{array}{l}\text { Intercept } \\
\text { trend }\end{array}$} \\
\hline & Intercept & $\begin{array}{l}\text { Intercept and } \\
\text { trend }\end{array}$ & Intercept & \\
\hline $\ln (\mathrm{GDPC})$ & $-2.903711^{c}$ & $-4.230916^{\mathrm{a}}$ & -1.696526 & -2.666658 \\
\hline $\ln (\mathrm{GCF})$ & $-5.542900_{a}$ & $-8.525301 \mathrm{a}$ & $-14.21119^{a}$ & $-15.09022^{a}$ \\
\hline $\ln (\mathrm{EXP})$ & $-6.308640^{a}$ & $-6.247836^{a}$ & $-6.287583^{a}$ & $-6.225128^{\mathrm{a}}$ \\
\hline $\ln (\mathrm{IMP})$ & $-5.292363^{\mathrm{a}}$ & $-5.248770^{\mathrm{a}}$ & $-5.256254^{\mathrm{a}}$ & $-5.207559^{\mathrm{a}}$ \\
\hline
\end{tabular}

Furthermore, Table IV represents the co-integration test analysis, and the existence of a long run relationship has been established among the model's variables. Results show that the computed F-statistics are 5.28 the relevant critical value bounds at ten percent level (with unrestricted intercept and no trend) are 5.28 and for the lower and upper bounds respectively. Then, the computed F-statistics is higher than the critical value of the upper bound, the null hypothesis of no long run co-integration correlation among the variables can be simply rejected.

Table IV: Results from bound tests.

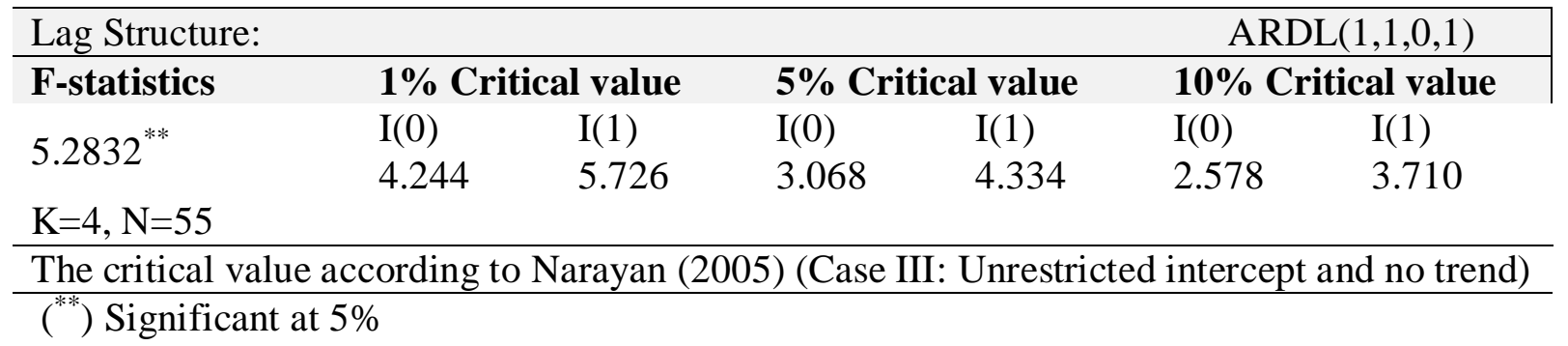

Table $\mathrm{V}$ shows the estimated coefficients of the long-run association which are significant for GCF, these are also significant for trade (Export + Import). In addition; GCF has a positive and significant impact on GDPC at the $1 \%$ level. This is illustrating that the growing correlation between gross capital formation and economic growth in China. Which motivate the inflow of an economic activity?

Muhammad Shahbaz and Saleheen Khan (2013) found that their empirical evidence confirmed our finding and they illustrated that long run relationship among the variables such as financial development, capital, exports, imports and international trade have positive impact on economic growth. 
Table V: LONG RUN RELATIONSHIPS

ARDL(1,1,0,1) selected based on Schwarz Bayesian Criterion

\begin{tabular}{llll}
\hline Variable & Coefficient & t-Statistic & Probability \\
\cline { 2 - 2 } Constant & & & \\
$\ln \left(G C F_{t}\right)$ & -17.5161 & -1.9877 & .053 \\
$\ln \left(E X_{t}\right)$ & $6.1114^{\mathrm{a}}$ & 2.2722 & .028 \\
$\ln \left(I M P_{t}\right)$ & $9.1433^{\mathrm{a}}$ & 2.4112 & .020 \\
R-squared & $-7.7830^{\mathrm{a}}$ & -2.1230 & .039 \\
F-statistic & .99718 & & \\
DW-statistic & 5.28 & & \\
(a) Significant at $1 \% .^{(2.1787}$ & &
\end{tabular}

Moreover, all variables are also passes all diagnostic tests against serial correlation (Durbin Watson test and Breusch- Godfrey test), heteroskedasticity (White heteroskedasticity test), and normality of errors (Jarque-Bera test). The Ramsey RESET test also suggests that the model is well specified as shown in table VI.

Table VI: Results of diagnostic tests

\begin{tabular}{lll} 
Test statistics: & $\mathrm{x}^{2}$ statistic & Probability \\
\hline Jarque-Bera(normality) & 7.1606 & $\mathrm{n} / \mathrm{a}$ \\
LM test (1) correlation & .52178 & .470 \\
ARCH test & 1.0832 & .298 \\
Ramsey RESET test & 5.9190 & .015 \\
CUSUM test & Stable & Stable \\
CUSUMQ test & Stable & Stable
\end{tabular}

Table V reveals the result of Granger causality test, there is a unidirectional relationship running from GDP per capita to trade (Export + Import). This is shows that GDP is very important to the trade sector in China and efforts need to be geared towards improving the GDP per capita to increase the trade and development in China.

Furthermore, Muhammad Shahbaz and Saleheen Khan (2013) also found that their empirical evidence supported our investigation and they showed that The Granger causality analysis revealed that unidirectional causal relationship running from economic growth and, international trade and economic growth.

Table VII: Granger Causality Test

\begin{tabular}{lc}
\hline Null Hypothesis & F-Statistic(Prob.) \\
LGDPC does not Granger Cause LEXP & $1.33241(0.2732)$ \\
LEXP does not Granger Cause LGDPC & $10.5017^{*}(0.0095)$ \\
LIMP does not Granger Cause GDPC & $4.45103^{*}(0.0167)$ \\
GDPC does not Granger Cause LIMP & $1.64071^{*}(0.2043)$ \\
\hline${ }^{*}$ denotes Significant at 1\%, . The number of lags is 2.
\end{tabular}


Finally, when analyzing the stability of the long-run coefficients together with the cumulative sum (CUSUM) and the cumulative sum of squares (CUSUMQ) which are applied Following as Pesaran cited in Bahmani-Oskooee (2001), the stability of the regression coefficients is evaluated by stability tests and they can explain whether or not the model equation is stable over time. This stability test is appropriate in time series data, especially when we are unsure about when structural change may be have taken place. CUSUM and CUSUMQ statistics are plotted against the critical bound of 5\% significance. According to Bahmani-Oskooee and Wing NG (2002), if the plot of these statistics remains within the critical bound of the $5 \%$ significance level, the null hypothesis (i.e. That all coefficients in the error correction model are stable) cannot be rejected. The plot of the cumulative sum of the recursive residual is presented in graph 1-2. As shown, the plot of both the CUSUM and the CUSUMQ residual are within the boundaries. That is to say that the stability of the parameters has remained within its critical bounds of parameter stability. It is clear from both the graphs presented in Figure (1-2) that both the CUSUM and the CUSUMQ tests confirm the stability of the long-run coefficients.

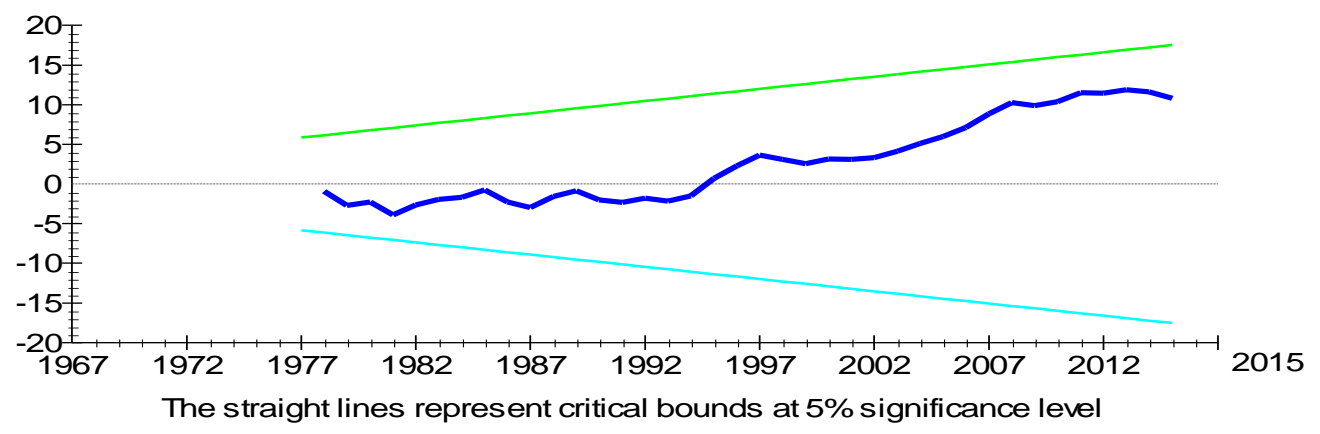

Figure 1: Cumulative Sum Of Recursive Residuals

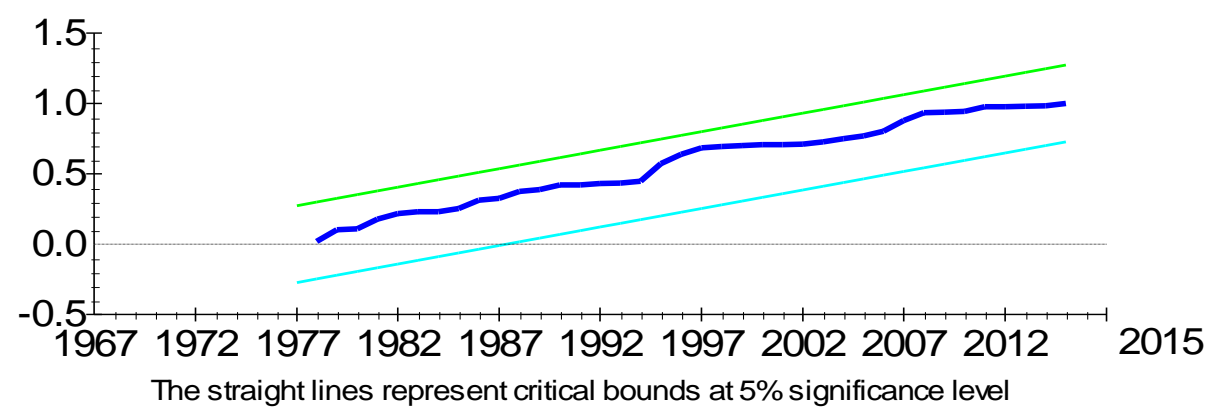

Figure 2: Cumulative Sum Of Squares Of Recursive Residuals

\section{Conclusions}

In this paper, we have applied the autoregressive distributed lag (ARDL) and granger causality model of trade openness and economic growth in China. Our results suggest that trade openness may impact favorably on growth of real GDP per capita. On the other hand, the impact would appear to be lagged and relatively modest. It means that trade different in their intensity and depth, or never amount to an immediate shift to free trade. 
The trade openness, which are picked up, are often first rather than final steps. Through time of course economies become more open, partly as a consequence of incremental trade reforms but also due to other factors such as reductions in communication costs transportation, and technological change. The pay-off to this increased openness may be greater, as manifested in consistently higher coefficients from the Sachs-Warner proxy. Our results suggest that four factors might be at work in explaining why the previous literature on the trade-growth relationship is so inconsistent. Firstly, there is a sample sizes and composition differ as do methodological approaches. Secondly, different analysts have been used various measures; some are ex ante indicators of trade openness, some are ex post and others are clearly indicators of openness. Finally, it is obvious that many econometrics models which have been estimated are miss-specified.

\section{References}

[1] Acemoglu, Daron, Johnson, Simon, Robinson, James A., 2001. The colonial origins of comparative development: an empirical investigation. American Economic Review 91 (5), 13691401 (December).

[2] Acemoglu, Daron, Johnson, Simon, Robinson, James A., 2005. Institutions as the fundamental cause of long-run growth. In: Aghion, Philippe, Durlauf, Steven N. (Eds.), Handbook of Economic Growth, volume 1A. North-Holland, pp. 386-472 (chapter 6).

[3] Alcalá, Francisco, Ciccone, Antonio, 2004. Trade and productivity. Quarterly Journal of Economics 119 (2), 613-646 (May).

[4] Alesina, Alberto, Devleeschauwer, Arnaud, Easterly, William, Kurlat, Sergio, Wacziarg, Romain, 2003. Fractionalization. Journal of Economic Growth 8 (2), 155-1994 (June).

[5] Alesina, Alberto, Spolaore, Enrico, Wacziarg, Romain, 2005. Trade, growth and the size of countries. In: Aghion, Philippe, Durlauf, Steven N. (Eds.), Handbook of Economic Growth, volume 1B. North-Holland, pp. 1499-1542 (chapter 23).

[6] Balassa, Bela, 1978. Exports and economic growth: further evidence. Journal of Development Economics 5 (2), 181-189 (June).

[7] Banks, Arthur S., 2001. Cross-National Time-Series Data Archive. Center for Social Analysis at the State University of New York (Binghamton), Binghamton (Web page: http://www.databanks.sitehosting.net/Default.htm).

[8] Barro, Robert J., 1991. Economic growth in a cross section of countries. Quarterly Journal of Economics 106 (2), 407-443 (May).

[9] Barro, Robert J., Lee, Jong-Wha, 1994. Data set for a panel of 138 countries. Technical Report (Downloadable at http://www.nber.org/pub/barro.lee/).

[10] Ben-David, Dan, 1993. Equalizing exchange: trade liberalization and income convergence. Quarterly Journal of Economics 108 (3), 653-679 (August).

[11] Ben-David, Dan, 1996. Trade and convergence among countries. Journal of International Economics 40 (3-4), 279-298 (May).

[12] Bils, Mark, Klenow, Peter J., 2000. Does schooling cause growth? American Economic Review 90 (5), 1160-1183 (December).

[13] Bloom, David E., Sachs, Jeffrey D., Collier, Paul, Udry, Christopher, 1998. Geography, demography, and economic growth in Africa. Brookings Papers on Economic Activity 1998 (2), 207-295.

[14] Brock, William A., Durlauf, Steven N., 2001. Growth empirics and reality. World Bank Economic Review 15 (2), 229-272.

[15] Brock, William A., Durlauf, Steven N., West, Kenneth D., 2003. Policy evaluation in uncertain economic environments (with discussion). Brookings Papers on Economic Activity (1), 235-321. 
[16] Center for International Development at Harvard University, a. Research Datasets. Web page: http://www.cid.harvard.edu/ciddata/ciddata.html (Boston, MA).

[17] Ciccone, Antonio, Jarociński, Marek, 2010. Determinants of economic growth: will data tell? American Economic Journal: Macroeconomics 2 (4), 222-246 (October).

[18] Cuaresma, Jesus Crespo, Doppelhofer, Gernot, 2007. Nonlinearities in cross-country growth regressions: a Bayesian averaging of thresholds (bat) approach. Journal of Macroeconomics 29 (3), 541-554 (September).

[19] Diamond, Jared, 1998. Guns, Germs and Steel: A Short history of everybody for the Last 13,000 Years. Vintage, London.

[20] Dollar, David, 1992. Outward-oriented developing economies really do grow more rapidly: evidence from 95 LDCs, 1976-1985. Economic Development and Cultural Change 40 (3), 523544 (April).

[21] Dollar, David, Kraay, Aart, 2003. Institutions, trade, and growth. Journal of Monetary Economics 50 (1), 133-162 (January).

[22] Durlauf, Steven N., Johnson, Paul A., 1995. Multiple regimes and cross-country growth behaviour. Journal of Applied Econometrics 10 (4), 365-384 (October-December).

[23] Durlauf, Steven N., Kourtellos, Andros, Tan, Chih Ming, 2008a. Are any growth theories robust? The Economic Journal 118 (527), 329-346 (March).

[24] Durlauf, Steven N., Kourtellos, Andros, Tan, Chih Ming, 2008b. Empirics of growth and development. In: Krishna Dutt, Amitava, Ros, Jamie (Eds.), International Handbook of Development Economics, volume 1-2. Edward Elgar, Cheltenham, UK, pp. 32-47 (chapter 3).

[25] Easterly,William, Levine, Ross, 2003. Tropics, germs, and crops: how endowments influence economic development. Journal of Monetary Economics 50 (1), 3-39 (January).

[26] Edwards, Sebastian, 1992. Trade orientation, distortions and growth in developing countries. Journal of Development Economics 39 (1), 31-57.

[27] Edwards, Sebastian, 1993. Openness, trade liberalization, and growth in developing countries. Journal of Economic Literature 31 (3), 1358-1393 (September).

[28] Edwards, Sebastian, 1998. Openness, productivity and growth: what do we really know? The Economic Journal 108 (447), 383-398 (March).

[29] Eicher, Theo S., Papageorgiou, Chris, Raftery, Adrian E., 2011. Default priors and predictive performance in Bayesian model averaging, with application to growth determinants. Journal of Applied Econometrics 26 (1), 30-55 (January/February).

[30] Eris, Mehmet, 2010. Population heterogeneity and growth. Economic Modelling 27 (5), 12111222 (September).

[31] Feder, Garshon, 1982. On exports and economic growth. Journal of Development Economics 12 (1-2), 59-73.

[32] Fernández, Carmen, Ley, Eduardo, Steel, Mark, 2001a. Benchmark priors for Bayesian model averaging. Journal of Econometrics 100 (2), 381-427.

[33] Fernández, Carmen, Ley, Eduardo, Steel, Mark, 2001b. Model uncertainty in cross country growth regressions. Journal of Applied Econometrics 16 (5), 563-576.

[34] Fischer, Stanley, 1993. The role of macroeconomic factors in growth. Journal of Monetary Economics 32 (3), 485-512 (December).

[35] Frankel, Jeffrey A., Romer, David, 1999. Does trade cause growth? American Economic Review 89 (3), 379-399 (June).

[36] Gallup, John Luke, Sachs, Jeffrey D., Mellinger, Andrew D., 1999. Geography and economic development. International Regional Science Review 22 (2), 179-232 (August).

[37] Gelman, Andrew, Carlin, John B., Stern, Hal S., Rubin, Donald B., 2004. Bayesian Data Analysis, 2nd edition. Chapman \& Hall/CRC, Boca Raton, Florida.

[38] George, Edward I., Foster, Dean P., 2000. Calibration and empirical Bayes variable selection. Biometrika 87 (4), 731-747 (December). 
[39] Global Development Network, 2005. Growth Database. New York University Development Research Institute, New York.

[40] Grossman, Gene M., Helpman, Elhanan, 1991. Innovation and Growth in the Global Economy. MIT Press, Cambridge, USA and London, UK.

[41] Gylfason, Thorvaldur, Zoega, Gylfi, 2006. Natural resources and economic growth: the role of investment. World Economy 29 (8), 1091-1115 (August).

[42] Hall,Robert E., Jones, Charles I., 1999. Why do some countries produce somuchmore output per worker than others? Quarterly Journal of Economics 114 (1), 83-116 (February).

[43] Harrison, Ann, 1996. Openness and growth: a time-series, cross-country analysis for developing countries. Journal of Development Economics 48 (2), 419-447 (March).

[44] Heston, Alan, Summers, Robert, Aten, Bettina, October 2002. Penn World Table Version A Center for International Comparisons at the University of Pennsylvania (CICUP) (Available at http://pwt.econ.upenn.edu/).

[45] Jeffreys, Harold, 1983. Theory of Probability, third edition. Clarendon, Oxford.

[46] Kass, Robert E., Raftery, Adrian E., 1995. Bayes factors. Journal of the American Statistical Association 90 (430), 773-795 (June).

[47] Kass, Robert E., Wasserman, Larry, 1995. A reference Bayesian test for nested hypotheses and its relationship to the Schwarz criterion. Journal of the American Statistical Association 90 (431), 928-934 (September).

[48] Kourtellos, Andros, Ming Tan, Chih, Zhang, Xiaobo, 2007. Is the relationship between aid and economic growth nonlinear? Journal of Macroeconomics 29 (3), 515-540 (September).

[49] Kourtellos, Andros, Stengos, Thanasis, Ming Tan, Chih, 2010. Do institutions rule? The role of heterogeneity in the institutions vs. geography debate. Economics Bulletin 30 (3), 1710-1719 (July).

[50] La Porta, Rafael, Lopez-de-Silanes, Florencio, Shleifer, Andrei, Vishny, Robert, 1999. The quality of government. Journal of Law, Economics, and Organization 15 (1), 222-279 (March).

[51] Leamer, Edward E., 1988. Measures of Openness. In: Baldwin, Robert E. (Ed.), Trade Policy Issues and Empirical Analysis. University of Chicago, Chicago and London, pp. 147-204.

[52] Lee, Jong-Wha, 1993. International trade, distortions, and long-run economic growth. IMF Staff Papers 40 (2), 299-328 (June).

[53] Ley, Eduardo, Steel, Mark F.J., 2009. On the effect of prior assumptions in Bayesian model averaging with applications to growth regression. Journal of Applied Econometrics 24 (4), 651674 (June/July).

[54] Liang, Feng, Paulo, Rui, Molina, German, Clyde, Merlise A., Berger, Jim O., 2008. Mixtures of g priors for Bayesian variable selection. Journal of the American Statistical Association 103 (481), 410-423 (March).

[55] Madigan, David, York, Jeremy, 1995. Bayesian graphical models for discrete data. International Statistical Review 63 (2), 215-232 (August).

[56] Mankiw, Gregory N., Romer, David, Weil, David N., 1992. A contribution to the empirics of economic growth. Quarterly Journal of Economics 107 (2), 407-437 (May).

[57] Marshall, Monty G., Jaggers, Keith, Robert Gurr, Ted, 2005. Polity IV Project: Political Regime Characteristics and Transitions. Center for International Development and Conflict Management at the University of Maryland, Maryland 1800-2003 (Available at http://www.cidcm.umd.edu/polity/).

[58] MASOUD ALI KHALID, 2016, The Impact of Trade Openness on Economic Growth in the Case of Turkey, Research Journal of Finance and Accounting Vol.7, No.10, 2016. www.iiste.org

[59] MASOUD ALI KHALID, 2017, Dynamic estimation of the relationship between trade openness and economic growth in Singapore, The Scientific Journal of Cihan University Sulaimanyia- Vol. (1) Issue (1)

[60] Minier, Jenny, 2007. Institutions and parameter heterogeneity. Journal of Macroeconomics 29 (3), 595-611 (September). 
[61] Mirestean, Alin, Tsangarides, Charalambos G., 2009. Growth determinants revisited. Working Paper. International Monetary Fund, Washington, D.C. (December).

[62] Moral-Benito, Enrique, 2012. Determinants of economic growth: a Bayesian panel data approach. The Review of Economics and Statistics 94 (2), 566-579 (May).

[63] North, Douglass C., 1990. Institutions, Institutional Change and Economic Performance. Cambridge University Press, Cambridge.

[64] Papageorgiou, Chris, 2002. Trade as a threshold variable for multiple regimes. Economics Letters 77 (1), 85-91 (September).

[65] Political Risk Services, a. International Country Risk Guide (ICRG). Political Risk Services Group Data Base: 1984-2002. Web page: http://www.prsgroup.com/ICRG.aspx.

[66] Pritchett, Lant, 1996. Measuring outward orientation in LDCs: can it be done? Journal of Development Economics 49 (2), 307-335.

[67] Pritchett, Lant, 2001. Where has all the education gone? The World Bank Economic Review 15 (3), 367-391.

[68] Przeworski, Adam, Limongi, Fernando, 1993. Political regimes and economic growth. Journal of Economic Perspectives 7 (3), 51-69 (Summer).

[69] Raftery, Adrian E., Madigan, David, Hoeting, A. Jennifer, 1997. Bayesian model averaging for linear regression models. Journal of the American Statistical Association 92 (437), 179-191 (March).

[70] Ram, Rati, 1987. Exports and economic growth in developing countries: evidence from timeseries and cross-section data. Economic Development and Cultural Change 36 (1), 51-72.

[71] Rivera-Batiz, Luis A., Romer, Paul M., 1991. International trade with endogenous technological change. European Economic Review 35 (4) (May).

[72] Rodrik, Dani, 2003. What do we learn from country narratives? In: Rodrik, Dani (Ed.), Search of Prosperity: Analytic Narratives on Economic Growth. Princeton University Press, pp. 1-19 (chapter 1 (Introduction), July).

[73] Rodrik, Dani, Rodríguez, Francisco, 2000. Trade policy and economic growth: a skeptic's guide to the cross-national evidence. In: Bernanke, Ben, Rogoff, Kenneth (Eds.), NBER Macroeconomics Annual, volume 15. MIT Press, Cambridge, USA, pp. 261-325.

[74] Rodrik, Dani, Subramanian, Arvind, Trebbi, Francesco, 2004. Institutions rule: the primacy of institutions over geography and integration in economic development. Journal of Economic Growth 9 (2), 131-165 (June).

[75] Sachs, Jeffrey D., Warner, Andrew M., 1995. Economic reform and the process of global integration. Brookings Papers on Economic Activity 1.

[76] Sachs, Jeffrey D., Warner, Andrew M., 1997. Natural resource abundance and economic growth. Working Paper, Center for International Development at Harvard University (November. available at http://www.ksg.harvard.edu/CID.html).

[77] Sala-i-Martin, Xavier X., 1997. I just run two million regressions. American Economic Review 87 (2), 178-183 (May).

[78] Sala-i-Martin, Xavier, Doppelhofer, Gernot, Miller, Ronald I., 2004. Determinants of long-term growth: a Bayesian Averaging of Classical Estimates (BACE) approach. American Economic Review 94 (4), 813-835 (September).

[79] Ulaşan, Bülent, 2012. Openness to international trade and economic growth: a crosscountry empirical investigation. Economics Discussion Papers 2012-25. Kiel Institute for the World Economy (May. http://www.economics-ejournal.org/economics/discussionpapers/2012-25).

[80] UNCTAD, 2008. Handbook of Statistics. United Nations Conference on Trade and Development, New York.

[81] Vamvakidis, Athanasios, 1999. Regional trade agreements or broad liberalization: which path leads to faster growth? IMF Staff Papers 46 (1), 42-68 (March).

[82] Wacziarg, Romain, 2001. Measuring the dynamic gains from trade. World Bank Economic Review 15 (3), 393-429. 
[83] Wacziarg, Romain, Welch, Karen Horn, 2008. Trade liberalization and growth: new evidence. World Bank Economic Review 22 (2), 187-231.

[84] Wasserman, Larry, 2000. Bayesian model selection and model averaging. Journal of Mathematical Psychology 44 (1), 92-107 (March).

[85] Weber, Max, 1930. The Protestant Ethic and the Spirit of Capitalism. Allen and Unwin, London (Reprinted by Routledge in 2006, London and New York).

[86] World Bank, 2002, 2006. World Development Indicators (CD-ROM data) (Washington, DC).

[87] Muhammad Shahbaz, Saleheen Khan, Mohammad Iqbal Tahir. (2013) The dynamic links between energy consumption, economic growth, financial development and trade in China: Fresh evidence from multivariate framework analysis. Energy Economics 40 (2013) 8-21

[88] Coe D.T. and E. Helpman (1995), International R\&D spillovers, NBER Working Paper, No. 4444.

[89] Maizels A. (1963), Industrial growth and World Trade, Cambridge University Press.

[90] Bahmani-Oskooee, M. (2001), "Real and Nominal Effective Exchange Rates of Middle Eastern Countries and Their Trade Performance", Applied Economics, Vol. pp. 103-111.

[91] Bahmani-Oskooee, M and Wing NG, R.C. (2002). " Long-run Demand for money in Hong Kong: An application of the ARDL model." International journal of Business and Economics, 2002,Vol.1, No.2, 147-155.

[92] Narayan, P. K. (2005). The saving and investment nexus for China: evidence from cointegration tests. Applied Economics, 37(17), 1979-1990.

[93] Pesaran, M. H., Shin, Y., \& Smith, R. J. (2001). Bounds testing approaches to the analysis of level relationships. Journal of applied econometrics, 16(3), 289-326.

[94] Dickey, D. A. and W. A. Fuller (1979). Distribution of the estimators for autoregressive time series with a unit root. Journal of the American statistical association 74(366a): 427-431.

[95] Phillips, P.C.B., Perron, P., 1988. Testing for a unit root in time series regression. Biometrika 75, 335-346. Rodriguez, F., Rodrik, D., 1999. Trade Policy and Economic Growth: A Skeptic's Guide to the Cross-National Evidence Working Paper 7081, NBER.

[96] Mintz, A., \& Huang, C. (1990). Defense Expenditures, Economic Growth, and The" Peace Dividend". The American Political Science Review, 84(4) 1283-1293.

[97] Hassan, M.S. and R. Kalim, 2012. Military expenditure and poverty in Pakistan: A Complex Phenomenon.

[98] Engle, R. F., Granger, C. W., \& Hallman, J. J. (1989). Merging short-and long-run forecasts: An application of seasonal cointegration to monthly electricity sales forecasting. Journal of econometrics, 40(1), 45-62.

[99] Pesaran, M.H., Shin, Y., Smith, R.J., 2001. Bounds testing approaches to the analysis of level relationship. Journal of Applied Economics 16, 289-326.

[100] (WDI 2016).

*Corresponding author.

E-mail address: masoudqajry@ yahoo.com 